\title{
Hepatitis B in symptomless Danish homosexual men
}

\author{
LARS K MUNCK, * CARSTEN S PETERSEN, $\dagger$ KARINE BECH,* \\ ÅGE CHR THOMSEN,* SUSANNE KROON, $\dagger$ ANNE-MARIE WORM, $\dagger$ \\ GUNHILD L WANTZIN, $\dagger$ JAN GERSTOFT $\ddagger$
}

From the Departments of * Medical Gastroenterology and †Dermatovenereology, Bispebjerg Hospital, and $\ddagger$ Rubella Department, Statens Seruminstitut, Copenhagen, Denmark

SUMMARY Forty eight symptomless homosexual men attending a sexually transmitted disease (STD) clinic and found by screening to have hepatitis B surface antigen (HBsAg) were followed up for a median of 10 (range six to 26) months to characterise their liver disease. Initially $33 / 50(66 \%)$ of the men had increased serum liver enzyme activity and 19/47 (40\%) had increased serum immunoglobulin $\mathrm{G}$ concentrations. Liver biopsy specimens showed acute hepatitis B in $12(39 \%)$ and chronic hepatitis $B$ in $19(61 \%)$ of the 31 patients who underwent liver biopsy. The course of the infection was: acute hepatitis B in 14/48 (29\%), chronic persistent hepatitis B in $23 / 48(48 \%)$, chronic aggressive hepatitis $\mathrm{B}$ in $8 / 48(17 \%)$, and cirrhosis in $3 / 48(6 \%)$ of the patients. Antibodies against human immunodeficiency virus (HIV) were present in $16 / 45(36 \%)$ of the patients, but the presence of antibodies to HIV did not influence the course of hepatitis B in the observation period.

Infection with hepatitis B virus (HBV) is endemic in homosexual men, and hepatitis B is a sexually transmitted disease (STD). ${ }^{1-6}$ Previous studies have documented a high incidence of symptomless hepatitis $B$ that may be associated with progressive liver disease. ${ }^{7-9}$ The purpose of this study was to characterise the liver disease in a group of symptomless homosexual men who attended an STD clinic and were found to have hepatitis B surface antigen ( $\mathrm{HBsAg}$ ), and to study the course of the hepatitis B in relation to concomitant infection with human immunodeficiency virus (HIV).

\section{Patients and methods}

\section{PATIENTS}

From January 1984 to September 1985 we screened for serological evidence of hepatitis B 817 homosexual men who attended the STD clinic at Rudolph Berghs Hospital, Copenhagen. We found $\mathrm{HBsAg}$ in $50(6 \%)$ of the men and antibody to HBsAg (anti-HBs) in 409 $(50 \%)$. We consecutively referred the 50 with $\mathrm{HBsAg}$ for further medical evaluation. Two failed to attend follow up within three months without their $\mathrm{HBsAg}$ having been cleared, and were excluded from analysis.

The remaining 48 men were followed up at regular

Address for reprints: Dr Lars K Munck, Department of Medicine B, Bispebjerg Hospital, DK-2400 Copenhagen NV, Denmark

Accepted for publication 25 March 1987 intervals for a median of 10 months (range six to 26 months). Their median age was 28 (range 20 to 67). Liver biopsy, which was offered to all men with persisting $\mathrm{HBsAg}$ or biochemical evidence of liver injury, was performed in 31 . Of the 48 men, $31(65 \%)$ had previously experienced one or more STD and 35 (73\%), including five with syphilis, had acute STDs on admission. None had symptoms or signs of hepatitis, but six had histories of hepatitis B.

LABORATORY TESTS

The serological markers of hepatitis $B$ included $\mathrm{HBsAg}$, anti-HBs, hepatitis e antigen ( $\mathrm{HBeAg}$ ), and antibodies to hepatitis $\mathrm{e}$ antigen (anti-HBe) (AUSRIA-II, AUSAB, $\mathrm{HBe} /$ anti-HBe, Abbot Laboratories). Antibodies to HIV (anti-HIV) were detected by an enzyme linked immunosorbent assay (ELISA) and checked by western blotting. ${ }^{10}$ Liver function was tested by measuring serum aspartate aminotransferase (AST), alkaline phosphatase, and gamma-glutamyl-aminotransferease activities, concentrations of $\operatorname{IgG}, \lg \mathrm{A}, \operatorname{lgM}$, bilirubin, and albumin, and prothrombin times. Liver histology was classified in accordance with the criteria of an international liver study group." T lymphocyte subpopulations were estimated at the initial examination and regularly during follow up as described previously. ${ }^{12}$

STATISTICAL EVALUATION

Results are given in medians and ranges. Fisher's exact 
test was used with a $5 \%$ level of significance. The Mann-Whitney rank sum test for unpaired data was used to evaluate T lymphocyte subpopulations.

\section{Results}

Table 1 shows the serological markers of hepatitis B initially and at follow up. At the initial examination $32 / 48(67 \%)$ of the men had high liver enzyme activity, with a mean AST of 65 (range 41-993) IU/l (normal range 10-40 IU/l), and 19/47 (40\%) had high IgG concentrations with a range of $14 \cdot 9-21 \cdot 1 \mathrm{~g} / \mathrm{l}$ (normal range $5 \cdot 8-14 \cdot 3 \mathrm{~g} / \mathrm{l})$. Liver biopsy specimens from 31 men after a median of eight weeks (range four to 29 weeks) showed acute necrotic hepatitis B (in six men), non-specific hepatitis (six), chronic persistent hepatitis (nine), chronic aggressive hepatitis B (seven), and cirrhosis (three).

The 48 men were followed up for a median of 10 months (range six to 26 months), and the course of their hepatitis B was investigated on the basis of histological, biochemical, and serological variables (table 2). Anti-HIV was found in $16 / 45(36 \%$ ), including two who developed antibodies during follow up. The finding of anti-HIV correlated with neither biochemical abnormalities nor histological findings. AntiHIV was found in 4/13 men with acute hepatitis B compared with 11/29 with chronic hepatitis B (not a significant difference). In men with acute hepatitis $B$ their anti-HIV status made no difference to the rate of clearance of $\mathrm{HBsAg}$. In men with chronic hepatitis $0 / 9$ with anti-HIV compared with $4 / 18$ without anti-HIV seroconverted to anti-HBe (not a significant difference).

Raised serum IgG concentrations were significantly $(p<0.05)$ more common in men infected with HIV than in those not infected, but were not related to chronic hepatitis B.

One man, who had non-specific hepatitis at biopsy and chronic persistent hepatitis B that had been documented nine years earlier when another biopsy specimen had been taken, developed the acquired immune difficiency syndrome (AIDS). His $\mathrm{HBsAg}$
Table 1 Serological markers of hepatitis $B$ in 48 symptomless homosexual men at screening and after follow up (median period 10 , range six to 26 , months)

\begin{tabular}{llll}
\hline & \multicolumn{3}{l}{ At follow up } \\
\cline { 3 - 4 } & $\begin{array}{l}\text { At initial } \\
\text { examination }\end{array}$ & $\begin{array}{l}\text { Acute } \\
\text { infection }\end{array}$ & $\begin{array}{l}\text { Chronic } \\
\text { infection }\end{array}$ \\
\hline $\begin{array}{c}\text { Serological markers } \\
\begin{array}{c}\text { Hepatitis B surface } \\
\text { antigen (HBsAg) }\end{array}\end{array}$ & 48 & 0 & 32 \\
$\begin{array}{c}\text { Antibody to HBsAg } \\
\text { (Anti-HBs) }\end{array}$ & 0 & 10 & 1 \\
$\begin{array}{c}\text { Neither HBsAg } \\
\text { nor anti-HBs }\end{array}$ & 0 & 4 & $1^{*}$ \\
$\begin{array}{c}\text { Hepatitis Be antigen } \\
\text { (HBeAg) }\end{array}$ & 37 & 0 & 26 \\
$\begin{array}{c}\text { Antibody to HBeAg } \\
\text { (Anti-HBe) }\end{array}$ & 8 & 12 & 6 \\
$\begin{array}{c}\text { Neither HBeAg } \\
\text { nor anti-HBe }\end{array}$ & 3 & 2 & 2 \\
\hline
\end{tabular}

*One man had cirrhosis.

cleared and he developed anti-HBs while he was seriously ill.

The figure shows $\mathrm{T}$ lymphocyte subpopulations in 30 men followed up for a median of 11 (range six to 26) months. Men with anti-HIV had significantly lower T helper cell counts $(p<0.02)$ and ratios of $T$ helper to $T$ suppressor cells $(\mathrm{H} / \mathrm{S}$ ratios $)(\mathrm{p}<0.02)$ than men without anti-HIV. Men with biochemical signs of liver injury had lower $\mathrm{H} / \mathrm{S}$ ratios $(\mathrm{p}<0.05)$ and $\mathrm{T}$ helper cell counts $(p<0.02)$ than those without. Lower $T$ helper cell counts were found in men with persisting $\mathrm{HBsAg}$ and $\mathrm{HBeAg}$ than in those whose antigens cleared $(p<0.01)$. This was also the case for the men without anti-HIV $(p<0.05)$. T helper cell counts were lower in the men with chronic hepatitis $B$ than in those with acute hepatitis $B(p<0.02)$, but the difference between anti-HIV positive and negative men was not significant.

Men with acute hepatitis $B$ had similar $\mathrm{H} / \mathrm{S}$ ratios to those with chronic hepatitis $B$, whether or not they had anti-HIV. None of the men with acute hepatitis B and no anti-HIV had $\mathrm{H} / \mathrm{S}$ ratios of 1.0 or less, whereas abnormally low $\mathrm{H} / \mathrm{S}$ ratios were registered in $9 / 20$ of the men with chronic hepatitis B including six with

Table 2 Liver disease in 48 symptomless homosexual men with hepatitis B surface antigen (HBsAg) followed up for a median of 10 , range six to 26 , months

\begin{tabular}{|c|c|c|c|c|c|c|c|}
\hline Diagnosis & No & $\begin{array}{l}\text { Abnormal } \\
\text { liver enzymes } \\
\text { at follow' up }\end{array}$ & $\begin{array}{l}\text { Raised IgG } \\
\text { concentrations } \\
\text { at follow' up* }\end{array}$ & $\begin{array}{l}\text { HBe Ag present } \\
\text { at follow up }\end{array}$ & $\begin{array}{l}\text { Liver biopsy } \\
\text { performed }\end{array}$ & $\begin{array}{l}\text { Anti-HIV } \\
\text { present }\end{array}$ & $\begin{array}{l}\text { Median (range) } \\
\text { follow up } \\
\text { (months) }\end{array}$ \\
\hline $\begin{array}{l}\text { Acute hepatitis B } \\
\text { Chronic persistent }\end{array}$ & 14 & 1 & $3 / 11$ & 0 & 7 & $4 / 13$ & $7(6-12) \dagger$ \\
\hline $\begin{array}{l}\text { hepatitis } \mathbf{B} \\
\text { Chronic aggressive }\end{array}$ & 23 & 10 & $12 / 19$ & 19 & 13 & $10 / 22$ & $12(6-25)$ \\
\hline $\begin{array}{l}\text { hepatitis B } \\
\text { Cirrhosis }\end{array}$ & $\begin{array}{l}8 \\
3\end{array}$ & $\begin{array}{l}7 \\
2\end{array}$ & $\begin{array}{l}7 \\
1\end{array}$ & $\begin{array}{l}6 \\
1\end{array}$ & $\begin{array}{l}8 \\
3\end{array}$ & $\begin{array}{l}1 / 7 \\
1 / 3\end{array}$ & $\begin{array}{l}15(9-26) \\
17(9-17)\end{array}$ \\
\hline
\end{tabular}

* Data were not available for all patients

+Median time to clearing of HBsAg 6.5 (range one to 8 ) months. 


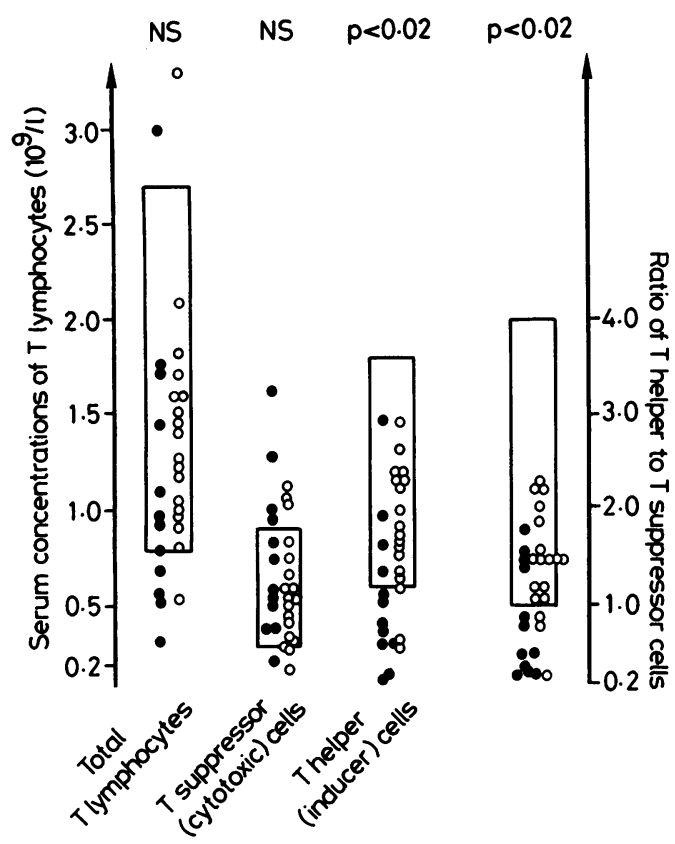

Figure Distribution of lymphocyte subpopulations in 30 symptomless homosexual men with hepatitis $B$ (boxes show normal ranges). (Differences between men with (O) and without ( $O$ ) antibodies to human immunodeficiency virus (HIV) by Mann-Whitney rank sum test for unpaired data).

simultaneous HIV infection. Men with raised serum IgG concentrations had lower $\mathrm{H} / \mathrm{S}$ ratios $(\mathrm{p}=0.01)$ and higher $T$ suppressor cell counts $(p<0.05)$. This could be explained by the HIV infection as mentioned above or by other concomitant infections.

\section{Discussion}

In this study of a group of symptomless homosexual men with hepatitis B detected by serological screening, most had histological evidence of chronic hepatitis. When followed up longitudinally, $71 \%(34 / 48)$ had a chronic course of the disease and $9 \%$ were healthy carriers. Our results agree with those of Ellis et al ${ }^{4}$ and Coleman.' The high prevalence of active contagious disease emphasises the importance of screening procedures in high risk groups of people attending STD clinics to evaluate hepatitis B when it is detected and to provide vaccine for non-infected men. ${ }^{6}$ This reservoir of $\mathrm{HBV}$, together with high levels of sexual activity, results in transmission of $\mathrm{HBV}$ in the subpopulation as indicated by the high prevalence of antiHBs. ${ }^{125}$

Anti-HIV was found in $36 \%$ (16/45) of our study population, which agrees with a simultaneous study from the same geographical area." ${ }^{15}$ The presence of anti-HIV apparently did not influence the course of the hepatitis B in our study population. A longer observation period will, however, probably be needed to further elucidate this aspect.

We showed a correlation between a low $\mathrm{H} / \mathrm{S}$ ratio, a decreased $\mathrm{T}$ helper cell count, and enhanced serum liver enzyme activity. We found no correlation between serological and morphological evidence of hepatitis $B$ and the $\mathrm{H} / \mathrm{S}$ ratio. The low $\mathrm{T}$ helper cell count could not be explained by only the simultaneous hepatitis B, as it was also suppressed in men with hepatitis B but no evidence of HIV infection. We could not confirm previous reports that the $\mathrm{H} / \mathrm{S}$ ratio is decreased in acute hepatitis B because of an augmented $\mathrm{T}$ suppressor cell count. ${ }^{14}$ I5 The findings in chronic hepatitis are heterogeneous. ${ }^{14} \mathrm{We}$ found no difference between acute and chronic hepatitis B either in $T$ helper cell counts or in $\mathrm{H} / \mathrm{S}$ ratios. Many of the homosexual men had STDs that might have induced abnormalities in the T lymphocyte phenotyping. ${ }^{12}$

In conclusion, we confirmed the existence of an infectious reservoir of symptomless homosexual men with chronic hepatitis B. The presence of HIV infection did not apparently influence the course of the hepatitis B.

We thank the departments of medicine at Glostrup Hospital, Frederiksberg Hospital, Roskilde Hospital, Holbæk Hospital, Herlev Hospital, and Gentofte Hospital and the department of infectious diseases, Rigshospitalet, University of Copenhagen, for their kind co-operation. We thank the department of pathology, Hvidovre Hospital, University of Copenhagen, for the histological evalution of the liver biopsy specimens. We thank Lisa Rohbach for typing the manuscript.

\section{References}

I Szmuness W, Much MI, Prince AM, et al. On the role of sexual behavior in the spread of hepatitis B infection. Ann Intern Med 1975;83:489-95.

2 Owen WF. Sexually transmitted diseases and traumatic problems in homosexual men. Ann Intern Med 1980;92:805-8.

3 Dietzman DE, Harnisch JP, Ray CG, Alexander ER, Holmes KK. Hepatitis B surface antigen ( $\mathrm{HBsAg}$ ) and antibody to $\mathrm{HBsAg}$. Prevalence in homosexual and heterosexual men. JAMA 1977; 238:2625-6.

4 Ellis WR, Murray-Lyon IM, Coleman JC, et al. Liver disease among homosexual males. Lancet 1979; i:903-5.

5 Schreeder MT, Thompson SE, Hadler SC. Hepatitis B in homosexual men: prevalence of infection and factors related to transmission. J Infect Dis 1982;146:7-15.

6 Petersen CS, Seier K, Kroon S, Worm A-M, Kryger P, Krogsgaard K. Hepatitis B in a venereological clientele in Copenhagen. Ugesk Lager 1984;146:1273-6.

7 Coleman JC, Evans BA, Thornton A, Zuckerman AJ. Homosexual hepatitis. $J$ Infect 1979;1:61-6.

8 Skinhøj P, Høybye G, Hentzer B, Faber V, Poulsen H. Chronic hepatitis $B$ infection in male homosexuals. J Clin Pathol 
1979;32:783-5.

9 Hoofnagle JH, Alter HJ. Chronic viral hepatitis. In: Vyas GN, Dienstag JL, Hoofnagle JH, eds. Viral hepatitis and liver disease. New York: Grune and Stratton, 1984;97-113.

10 Wantzin GL, Saxinger WC, Weismann K, Gallo RC. Human-Tlymphotropic retroviris type III (HTLV-III) in Danish homosexuals. Acta Derm Venereol (Stockh) 1985;65:247-50.

11 International group. Morphological criteria in viral hepatitis. Lancet 1971;i:333-7.

12 Gerstoft J, Petersen CS, Kroon S, et al. T-lymphocyte subsets in homosexual men from Copenhagen. Eur J Clin Invest 1984;14:
301-5.

13 Gerstoft J, Lindhart BØ, Petersen CS, et al. Antibodies to human T-cell lymphotropic virus type III in promiscuous healthy homosexual men. Relation to immunological and clinical findings. Eur J Clin Invest 1985;15:290-5.

14 Dienstag JL. Immunological mechanisms in chronic hepatitis. In: Vyas GN, Dienstag JL, Hoofnagle JH, eds. Viral hepatitis and liver disease. New York: Grune and Stratton, 1984;135-65.

15 Thomas HC, Brown D, Routhier G, et al. Inducer and suppressor T-cells in hepatitis B virus induced liver disease. Hepatology 1982;2:202-4. 